\title{
Against Supersessionist Thinking: Old and New, Jews and Postcolonialism, the Ghetto and Diaspora
}

\author{
Bryan Cheyette
}

\begin{abstract}
This essay focuses on the liberatory possibilities and political and disciplinary difficulties of bringing together Jewish and postcolonial studies. It begins and ends with Adorno's critique of "actionism" in order to see what is lost when the clarity and certainty of political action is privileged over scholarly nuance and complexity ("praxis" over "theory"). This loss is surveyed through a set of related binaries (supersessionism, foundationalism, and disciplinarity), which, it is contended, reduces critical thinking to polemic and makes it all but impossible to explore interconnected Jewish and postcolonial histories. The argument is illustrated with reference to postcolonial literature and by examining the disciplining of postcolonial and memory studies in relation to the Holocaust. A way out of the binary impasse, it is suggested, is to utilize as "traveling concepts" transcultural and transnational histories (such as "diaspora" and "ghetto") that Jewish and postcolonial studies have in common.
\end{abstract}

Keywords: actionism, Israel, Palestine, Rushdie, supersessionism, foundationalism, disciplinarity, ghetto, diaspora

In recent years there has been an increased interest in what this journal has called the "mutual filiations and genealogies" within Jewish and (post)colonial "historical constellations." A new collection, Colonialism and the Jews, has characterized these constellations, alongside the conflict in Israel/Palestine, as "Jewish-Muslim relations, the wider Middle East, the future of European identity, and the aims and roots of American empire." 2 The editors of Colonialism and the Jews contend that "typically,

Bryan Cheyette is Chair in Modern Literature and Culture at the University of Reading, and a Fellow of the English Association. He is the editor or author of ten books most recently Diasporas of the Mind: Jewish and Postcolonial Writing and the Nightmare of History (Yale University Press, 2014) and volume seven of the Oxford History of the Novel in English (on postwar British and Irish fiction) (Oxford University Press, 2016). His research interests include critical "race" studies, postcolonial literature and theory, diasporic literature, Holocaust testimony, and British-Jewish literature and culture. He has edited a special issue of Wasafiri and writes regularly for the Times Literary Supplement. He is currently working on a short book on the Ghetto for Oxford University Press and a longer book on Israel Zangwill entitled Israel Zangwill: Ghetto, Melting Pot, Zion.

1 Willi Goetschel and Ato Quayson, "Introduction: Jewish Studies and Postcolonialism," The Cambridge Journal of Postcolonial Literary Inquiry 3.1 (Winter 2015), 10 and throughout. See also Bryan Cheyette, ed., Wasafiri 57 (Spring 2009), "Jewish/Postcolonial Diasporas," 1-2 and throughout.

2 Ethan B. Katz, Lisa Moses Leff, and Maud S. Mandel, eds., Colonialism and the Jews (Bloomington: Indiana University Press, 2017), 1 and the Introduction. 
the subject of Jews and colonialism is hidden in plain sight, more polemicized or avoided than probed, let alone illuminated.... Until recently, scholars have offered little help." ${ }^{3}$ The reason, needless to say, for the lack of scholarly insight on all sides is the "place of colonialism in the history of Zionism and the State of Israel." From the perspective of postcolonial studies, "Jews and colonialism frequently became reduced to polemics over Zionism, flattening the issue rather than taking account of its nuances." ${ }^{4}$ What use is nuance when urgent political action is needed?

This is a question that goes back to Theodor Adorno's critique of "actionism" in the 1960s in response to the student protests of that era which he regarded as "regressive." As Willi Goetschel has shown, the debate between theory and praxis, or critique and politics, has a long genealogy that began with Spinoza. Adorno regarded praxis as theoretical and critique as social but was at pains to leave this dualism unresolved in the name of "humaneness": "humaneness awakes with the separation of theory and praxis; it knows nothing of that indifferentiation that in truth bows before the primacy of praxis." The reason why "actionism is regressive" is because "immediate action, which always evokes taking a swing, is incomparably closer to oppression than the thought which catches its breath."" For Adorno, "the thinking denigrated by actionists apparently demands of them too much undue effort: it requires too much work, is too practical." ${ }^{8}$ Rather than the supposed rationality and primacy of actionism, "in relation to real power, which hardly feels a tickle, actionism is irrational."

My essay will explore what is lost when we foreground the clarity and certainty of political action over scholarly nuance and complexity ("praxis" over "theory"). I will do this by highlighting a set of binaries in current usage that, I believe, reduces critical thinking to polemic. It may be a foolish enterprise, after Adorno, to try and unravel the confusion among, say, activism, critical thinking, and activist-scholarship with regard to Israel/Palestine (to take one example out of many) because this is, above all, a question of authority. Does the academy, in the twenty-first century, still have the authority to speak on such urgent political issues when most of the energy and "polemics over Zionism" takes place outside of the academy? Should the academy simply refuse any authority but its own critical thinking; or cede authority to extracurricular activists; or try, as I would want, to bridge the current divide between critical thinking and political action? But how can the language of the academy and of activism be bridged?

I will illustrate the long-recognized difficulties in bridging the language of critique and activism with an example taken from the special issue of this journal on Jewish

3 Katz, Leff, and Mandel, Colonialism and the Jews, 1.

4 Katz, Leff, and Mandel, Colonialism and the Jews, 2.

5 Theodor W. Adorno, Critical Models: Interventions and Catchwords, trans. Henry W. Pickford (New York: Columbia University Press, 2005), 273 and 259-88.

6 Adorno, Critical Models, 267. For the broader philosophical context of this debate, to which I am indebted, see Willi Goetschel, "Theory-Praxis: Spinoza, Hess, Marx, and Adorno," Bamidbar: Journal for Jewish Thought and Philosophy 2 (2013): 26 and 16-28.

7 Adorno, Critical Models, 273-74.

8 Adorno, Critical Models, 263.

9 Ibid., 271. 
and postcolonial studies. In their introduction, Willi Goetschel and Ato Quayson are at pains to remember Jewish and postcolonial history "in difference" with a "commitment to attending to the different singularities each case presents." ${ }^{10}$ The dialogue between Jewish and postcolonial studies, in other words, challenges a reductive analogical thinking and, instead, reimagines the "critical reciprocity" between the two histories. ${ }^{11}$ In contrast, Aamir Mufti, in an interview speaks of the "horrific dialectical reversal" that can turn "victims into perpetrators" or "Jews' into 'Germans," which, he recognizes, is "explosive and painful for both peoples I am naming here." ${ }^{\prime 2}$ What is more, and this I find equally painful, he speaks of "those folks in Jewish studies who have been generously receptive to the argument in Enlightenment in the Colony: The Jewish Question and the Crisis of Postcolonial Culture (2007)," such as myself, ${ }^{13}$ and hopes that "they are willing and able to extend their insights to Israel and the Palestinians" so as to assess "who are the fascists and who constitutes the vulnerable and brutalized population." 14 Such is the binary, analogical, and moralized world of political action that the "folks in Jewish studies" find themselves confronted with.

My point is not that Mufti is, reductively, calling for unthinking activism; not even in the interview where, in the spirit of the journal's introduction, he goes to great lengths to critique analogical thinking with regard to Enlightenment in the Colony. But the slippage into the crudest forms of analogical thinking at this point in the interview is illustrative of precisely what is lost when critical thinking is replaced by actionism. Although I disagree with the moralization of politics, I can understand why it might make sense, from an anti-Zionist perspective, to characterize Jewish majoritarianism in Israel/Palestine as "fascist" (following the "German" model). The logic here, which Edward Said explicitly and consistently rejected, is that the Palestinians are the "new Jews" superseding "the Jews" in their role as foundational world-historical victims. ${ }^{15}$ Turning Israel into a contemporary pariah state (with majoritarian Jews as the new "Germans") obviously follows the anti-apartheid politics in the second half of the twentieth-century in mobilizing the anticolonial left around a single cause. Omar Barghouti, for instance, one of the founders of the Boycott, Divestment and Sanctions (BDS) movement, describes it as "the South Africa strategy for Palestine." ${ }^{\text {"6 }}$ But this form of progressive exceptionalism merely mirrors the Israeli right who similarly proclaim an exceptionalism (in the form of "Jewish uniqueness"), which, in this reactionary sense, means that international law can be flouted with impunity.

10 Goetschel and Quayson, "Introduction: Jewish Studies and Postcolonialism," 3.

11 Goetschel and Quayson, "Introduction: Jewish Studies and Postcolonialism," 3.

12 Ato Quayson and Aamir R. Mufti, "The Predicaments of Postcolonial Thinking," Cambridge Journal of Postcolonial Literary Inquiry 3.1 (Winter 2015), 143-56.

13 Bryan Cheyette, "The Boy Singer Goes Global," Times Literary Supplement 5477 (March 21, 2008): $22-24$.

14 Quayson and Mufti, "The Predicaments of Postcolonial Thinking," 152.

15 For Said's rejection of the "new Jew" discourse, see Bryan Cheyette, "A Glorious Achievement: Edward Said and the Last Jewish Intellectual," in Tobias Döring and Mark Stein, eds., Edward Said's Translocations: Essays in Secular Criticism (London: Routledge, 2012), 78-81 and chapter four.

16 Omar Barghouti, BDS: Boycott, Divestment, Sanctions. The Global Struggle for Palestinian Rights (Chicago: Haymarket, 2011), chapter three. See also David Feldman, ed., Boycotts: Past and Present (London: Palgrave, 2018). 
The problem with moralizing politics (with one side uniquely outcast and the other side uniquely unique) is that both sides of the divide employ what they regard as an unimpeachable binary logic to their own ends.

There are three interrelated elements of this exceptionalist logic, which makes it particularly difficult to locate Jewish history within general history. The binaries that I will explore in these terms are: first, supersessionist thinking where the "new" replaces the "old" (as in "Jews" replacing "Germans"); second, disciplinary thinking (defining disciplines in relation to what is excluded); and, finally, foundational thinking (constructing Israel/Palestine or diaspora Jewish history as central or foundational). Although the "interface" ${ }^{17}$ between Jewish and postcolonial studies has long been recognized (going back to Hannah Arendt, Frantz Fanon, Aimé Césaire, Jean Améry, Jean-Paul Sartre, and Primo Levi), these commonalities "in difference" have only recently informed both Jewish and postcolonial studies. ${ }^{18}$ But, despite his own influential work, Mufti notes correctly that postcolonial studies has not yet been informed by the commonalities with Jewish studies despite other new comparative work by Marc Caplan, Sarah Casteel, Paul Gilroy, Anna Guttman, Isabelle Hesse, Michael Rothberg, and Maxim Silverman to name just a few examples. ${ }^{19}$ This is even more troubling when, as Goetschel and Quayson argue, the "Jewish experience of modernity can be said to provide fertile templates for understanding questions as varied as minoritarianism, diaspora, nostalgia, racialization, ethnicity, cultural difference, creolization, hybridity, and colonialism, all of which are central concerns in postcolonial studies." ${ }^{20}$ I will now explore the extent to which such "fertile templates" are negated by supersessionist thinking.

I characterize the structural question of supersessionist thinking, the first and most important of the binaries I wish to discuss, as the shift from old to new with the old, at one end of a polarity, characterized as "classic," and the new, at the other end, characterized as "contemporary." ${ }^{21}$ Ato Quayson has named this thinking, in general, as "chronological supersession." ${ }^{22}$ Supersessionist thinking began historically as a

17 Goetschel and Quayson, "Introduction: Jewish Studies and Postcolonialism," 3.

18 Bryan Cheyette, Diasporas of the Mind: Jewish and Postcolonial Writing and the Nightmare of History (New Haven, CT: Yale University Press, 2014), chapter one.

19 Marc Caplan, How Strange the Change: Language, Temporality, and Narrative Form in Peripheral Modernism (Palo Alto, CA: Stanford University Press, 2011); Sarah Casteel, Calypso Jews: Jewishness in the Caribbean Imagination (New York: Columbia University Press, 2016); Paul Gilroy, Between Camps: Race, Identity and Nationalism at the End of the Colour Line (London and New York: Penguin, 2000); Anna Guttman, Writing Indians and Jews: Metaphorics of Jewishness in South Asian Literature (London and New York: Palgrave 2013); Isabelle Hesse, The Politics of Jewishness: The Holocaust, Zionism, and Colonialism in Contemporary World Literature (London and New York: Bloomsbury 2016); Aamir Mufti, Enlightenment in the Colony: The Jewish Question and the Crisis of Postcolonial Culture (Princeton, NJ: Princeton University Press, 2007); Michael Rothberg, Multidirectional Memory: Remembering the Holocaust in the Age of Decolonization (Palo Alto, CA: Stanford University Press, 2009); and Maxim Silverman, Palimpsestic Memory: The Holocaust and Colonialism in French and Francophone Fiction and Film (Oxford: Berghahn, 2013). See also Quayson and Mufti, "The Predicaments of Postcolonial Thinking," 152.

20 Goetschel and Quayson, "Introduction: Jewish Studies and Postcolonialism," 6.

21 Ankhi Mukherjee, What Is a Classic? Postcolonial Rewriting and the Invention of the Canon (Palo Alto, CA: Stanford University Press, 2014); Roger Luckhurst and Peter Marks, eds., Literature and the Contemporary: Fictions and Theories of the Present (London and New York: Routledge, 1999).

22 Ato Quayson, Postcolonialism: Theory, Practice or Process? (Cambridge: Polity Press, 2000), 9. 
theological concept and is at the heart of a progressivist Western European Christian tradition as well as the "intraverted" management of heterogeneous minorities in the empty space of the Western nation-state. ${ }^{23}$ Supersessionist thinking grows out of the foundational belief that Christianity is the fulfilment of biblical Judaism (and is structured in secular terms around the "new" transcending or replacing the "old"; hence the Christian concepts of the "new" and "old" testaments) or, in theological terms, the "old" chosen people being fulfilled or replaced by a "new" Christian church. The most nuanced form of supersessionist thinking is known as "economic supersessionism" (as in the phrase being "economical with the truth"), which is still widely applied today. ${ }^{24}$

But, I should stress, that it is the secular application of such supersessionist thinking, which began in Western Europe in the nineteenth century, that interests me the most. ${ }^{25}$ At the same time, it will become apparent that there is always also a return of the repressed when it comes to the foundational thinking of the theological. The recent appropriation of a so-called postmodern or theo-political Pauline theology by Agamben, Badiou, and Zizek indicates the extent to which the secular and the theological are once again blurred in the name of Western universal values. ${ }^{26}$ After the exhaustion of "postmodernism" and "postcolonialism" as master signifiers of the contemporary, there remains a strange, vestigial search for new foundational narratives - a product of what David Shields calls "reality hunger" 27 and this "reality hunger" is the context for the turn, or return, to many other foundational narratives, including a foundational Pauline universalism but also a belief in the uncritical political authenticity of the actionist (pace Adorno) or what Fanon called (following Gramsci), the "organic intellectual" 28 as opposed to the rootless cosmopolitan academic.

In the case of Jewish and postcolonial studies, we have the shift from a supposedly old established discipline, which can be falsely constructed to be part of a so-called Judeo-Christian Western tradition (that is Ashkenazic Jewish studies), and a newer

23 For the distinction between "extraverted" and "intraverted" colonialism, see Quayson, "Comparative Postcolonialisms: Storytelling and Community in Sholem Aleichem and Chinua Achebe," Cambridge Journal of Postcolonial Literary Inquiry 3.1 (Winter 2015): 59 and 55-77. See also Goetschel, "Voices from the 'Jewish Colony': Sovereignty, Power, Secularization, and the Outside Within," International Relations and Non-Western Thought: Imperialism, Colonialism and Investigations of Global Modernity, ed. Robbie Shilliam (London: Routledge, 2010), 64-84; Susannah Heschel, "Jewish Studies as Counterhistory," Insider/Outsider: American Jews and Multiculturalism, eds. David Biale, Michael Galchinsky, and Susannah Heschel. (Los Angeles: University of California Press, 1998), chapter five.

24 For these distinctions see R. Kendall Soulen, The God of Israel and Christian Theology (Minneapolis: Fortress, 1996).

25 For the origins of secular supersessionism see Ivan Kalmar, "Arabizing the Bible: Racial Supersessionism in Nineteenth Century Christian Art and Biblical Criticism," Orientalism Revisited: Art, Land and Voyage, ed. Ian Richard Netton (London and New York: Routledge, 2012), 176-86.

26 Giorgio Agamben, The Time That Remains: A Commentary on the Letter to the Romans, trans. Patricia Dailey (Palo Alto, CA: Stanford University Press, 2006); Giorgio Agamben, The Mystery of Evil: Benedict XVI and the End of Days, trans. Adam Kotsko (Palo Alto, CA: Stanford University Press, 2017); Alain Badiou, Saint Paul: The Foundation of Universalism, trans. Ray Brassier (Palo Alto, CA: Stanford University Press, 2003); Slavoj Zizek, The Fragile Absolute: Or, Why Is the Christian Legacy Worth Fighting For? (London: Verso, 2009); Slavoj Zizek, Living in the End of Times: Updated New Edition (London: Verso, 2011).

27 David Shields, Reality Hunger: A Manifesto (London and New York: Penguin, 2010).

28 Frantz Fanon, The Wretched of the Earth, trans. Constance Farrington (New York: Grove, 1963$), 167$. 
discipline of postcolonial studies that is understandably deeply suspicious of this Western tradition and the narratives of victimhood as part of this tradition. ${ }^{29}$ Although it has long been recognized that, most prominently, Jews, slaves, the colonized, and women are victims of Western modernity, this has not led, with notable exceptions, to an intersectional critique of Western modernity from these different perspectives. ${ }^{30}$ In fact, it could be argued that such commonalities have not resulted in solidarity but have made it remarkably difficult, in its earliest institutional years, for postcolonial studies to identify too closely with Jewish studies. The very fact that these fields had so much in common meant that, paradoxically, the new had to be particularly differentiated from the old.

Disciplinary thinking, in this regard, is closely connected to supersessionist thinking. All academic disciplines are defined by what they leave out-what Jonathan Boyarin calls "discipline and exclude" or Gayatri Spivak calls "disciplinary fear" - which is what makes a new discipline "new." ${ }^{31}$ As Samuel Weber argues in his Institution and Interpretation: "[i]n order for the authority of the [university] professional to be recognized as autonomous, the 'field' of his 'competence' had to be defined as essentially self-contained. ... In general, the professional sought to isolate in order to control."32 Weber shows that it is "demarcation," above all, which "marks the professional perspective ... of the university professor." ${ }^{33}$ It is this disciplinary fear, exclusion, or demarcation that leads to the construction of the "classic" Jewish diaspora or ghetto, which is supposedly superseded or transcended by more recent formations.

These "classic" formations result in a centring of Jewish history as foundational to Western or European culture, which again stems from supersessionist thinking, and which, I believe, ought to be decentered so as to make Jewish history unexceptional. What is more, as Ankhi Mukherjee has shown, by locating "the classic" within Western culture, there is an implicit denigration of those colonized cultures that are assumed not to have produced classic formations. ${ }^{34}$ After the Holocaust, Jewish victimhood took center stage in Western culture (not least because a suffering Jew was at the heart of this culture), which has given it a foundational status in relation to memory studies. This foundational status, I will now show, is challenged most self-consciously in postcolonial imaginative literature (published at the same time as postcolonial studies was formed) with regard to what was perceived as a catastrophic and overwhelming Jewish history.

29 Non-European Sephardi Jewish history has been, until recently, excluded from this received account of a dominant white, Western Judeo-Christian tradition. For an early critique of this orthodoxy, see Marshall Grossman, "The Violence of the Hyphen in Judeo-Christian," Social Text 22 (Spring 1989): 115-22. A recent redress to this reduction can be found in Colonialism and the Jews, chapters two, five, seven, and eleven.

30 An exception to this rule is Gilroy's Between Camps. See also Bryan Cheyette and Laura Marcus, eds., Modernity, Culture and "the Jew" (Cambridge: Polity; Palo Alto, CA: Stanford University Press, 1998).

31 Gayatri Chakravorty Spivak, Death of a Discipline (New York: Columbia University Press, 2003$), 19$. See also Jonathan Boyarin, Thinking in Jewish (Chicago, IL: University of Chicago Press, 1996), 172.

32 Samuel Weber, Institution and Interpretation (Palo Alto, CA: Stanford University Press, 2001), 27 and chapter two.

33 Ibid., 32.

34 Mukherjee, What Is a Classic? Introduction. 
I have always found it beneficial to read imaginative postcolonial writers who were publishing at about the same time as postcolonial studies was being institutionalized in the 1980s and 1990s. The contrast between what is excluded or disciplined and what is imaginatively included is, I believe, most revealing. ${ }^{35}$ The first thing that need be said about such writers as Salmon Rushdie, V. S. Naipaul, and Anita Desai (and later Caryl Phillips and Zadie Smith) is that they do not distinguish in their fictions between Jewish and colonial history or anti-black and anti-Jewish racism. These writers have what has been felicitously called a "moral imagination" in this regard, which was also particularly valued by Adorno, who argued that the "lack of imagination that is instilled and inculcated by society renders people helpless." ${ }^{36}$ The contrast between imaginative and disciplinary approaches, when it comes to an intertwined Jewish and colonial history, could not be starker. As we know, Rushdie in his Imaginary Homelands manifesto includes "the Huguenots, the Irish, the Jews" as part of an alternative transnational minority tradition. ${ }^{37}$ These imagined moments of identification with diasporic Jews (as the most troublesome and troubling of Rushdie's troika) is an increasingly acknowledged feature of Rushdie's fiction over four decades (from Grimus [1975] to Shalimar the Clown [2005]), which is in stark contrast to the disciplinary formation of postcolonial studies. Rushdie, in The Moor's Last Sigh (1995), evokes the history of Spain (where Jews and Muslims lived together peacefully before they were expelled in 1492) and the history of Jewish communities in India, and, by the time of Shalimar the Clown, he also compares border states in Europe and Southeast Asia (Alsace and Kashmir) where, respectively, Jewish and Muslim "communities of ... suffering" have lived for centuries. ${ }^{38}$

But these interconnected histories-where the imagination sees "similarities in dissimilars" 39 - are not a sanguine coming together of different histories but are in competition and are part of a generational conflict. His fiction, in other words, enacts the struggle between "old" and "new" where the Jewish or Judaized father-figure is killed off or disempowered so as to enable the postcolonial voice to be heard. The urtext in this regard is Rushdie's first published novel, Grimus, an allegorical work of science fiction. This novel contrasts the overweening imagination of the patriarch Grimus, who was by his "accents" "evidently Middle-European, a refugee no doubt" and whose traumatic wartime experiences in a concentration camp meant that "the imagined world of books and philosophies and mythologies . . . became his realities." 40 Rushdie's postcolonial ("Flapping Eagle") resists "The Grimus Effect" in the novel,

35 For this argument in full see Cheyette, Diasporas of the Mind, chapter six. See also Martin Eve, Literature against Criticism: University English and Contemporary Fiction in Conflict (London: Open, 2016).

36 Adorno, Critical Models, 172; and Ato Quayson and Girish Daswani, eds., "Introduction: Diaspora and Transnationalism," A Companion to Diaspora and Transnationalism (Oxford: Blackwell, 2013), 16-19.

37 Salman Rushdie, Imaginary Homelands: Essays and Criticism 1981-1991 (London, 1991), 20.

38 Edward W. Said, The End of the Peace Process: Oslo and After (London, 2000), 208 and chapter thirty, which is a plea to end the impasse between "two communities of detached and uncommunicatingly separate suffering" in Israel/Palestine.

39 Hannah Arendt, The Life of the Mind (New York: Harcourt, 1971), 102-03. I contrast such metaphorical thinking with binary thinking in Diasporas of the Mind throughout.

40 Salman Rushdie, Grimus (London and New York: Penguin, 1975), 208, 243. 
which remakes the world in relation to Grimus's wartime traumas in the camps while disregarding the experience and emotions of his colonized counterpart.

The final part of Grimus charts the struggle of the youthful postcolonial to retain a sense of selfhood and autonomy in the face of Grimus's grand design. Flapping Eagle refuses to succumb to Grimus's stratagems and repudiates assimilation into Grimus's particular European history of suffering, which overdetermines the mind and eschews the body echoing Fanon's distinction between Jewishness and blackness in Black Skin, White Masks (1952). ${ }^{41}$ In the words of the narrator, the "mind of Grimus, rush[es] through"42 Flapping Eagle, who needs to find a voice and sense of self that is not dominated by the voice and history of Grimus, the "halfbreed semi-semitic prisoner of war." ${ }^{\prime 3}$ By the end of the novel, Flapping Eagle destroys the source of Grimus's power so that he can gain some autonomy. One way of reading Grimus is as a Fanonian allegory, which, in the end, privileges the body over the mind or a concrete sense of place (subject to the forces of history) over a "sterile" catastrophic landscape rooted in the overwhelming traumas of the past. Such an allegory also privileges colonial histories of suffering (located spatially) over indigenous European histories of genocide (located temporally) and enacts the kinds of anxieties that we have seen in the disciplinary formation of postcolonial studies. ${ }^{44}$ That the young postcolonial figure refuses to be assimilated into Grimus's traumatic post-holocaust creations refers, implicitly at least, to the postcolonial rethinking of the history of ghettoization, minoritization, and diaspora beyond its Jewish antecedents. By the time of Shalimar the Clown, published forty years after Grimus, the fraught opposition between a dominant and elderly camp survivor and a young and marginalized postcolonial is writ large.

Max Ophuls and the eponymous Shalimar are mature versions of Grimus and Flapping Eagle in Rushdie's first novel. They both emerge from border-territoriesAlsace and Kashmir-exactly the kind of places that have, historically, eschewed national boundaries. Max is a "Frenchman with a German name," and his family are influenced equally by both nations as "in civilization there are no borderlines." ${ }^{45}$ This blurring of boundaries is reflected in the Muslim Shalimar marrying a Hindu. With his "movie-star good looks," ${ }^{36}$ Max is suitably named after the German-Jewish émigré filmmaker and, not unlike his Hollywood namesake, engages in fakery on a worldwide stage after moving to the United States. In this he is a Grimus-figure par excellence, a bogus artist who, after the trauma of the Holocaust, detaches his imagination from reality so as to create a solipsistic "new world." ${ }^{\text {N7 }}$ Not unlike his prototype, Max's life after the Holocaust is "empty," an "open grave," 48 and this vacuum is filled by world-making. In contrast to Grimus, however, Rushdie's more mature novel focuses

41 Bryan Cheyette, "Frantz Fanon and the Black-Jewish Imaginary," Rereading "Black Skin White Masks," ed. Maxim Silverman (New York and Manchester: Manchester University Press 2006), 74-99.

42 Rushdie, Grimus, 243.

43 Ibid.

44 Jonathan Boyarin, Storm from Paradise: The Politics of Jewish Memory (Minneapolis, MN: University of Minnesota Press, 1992), 82 and chapter five.

45 Salman Rushdie, Shalimar the Clown (London: Jonathan Cape, 2005), 141.

46 Ibid., 161.

47 Ibid., 20.

48 Ibid., 33. 
on the politics of being a "maker of the world." ${ }^{49}$ Max, we are told, was privy to the proposals to bring the Council of Europe, the International Monetary Fund, and the World Bank into being after World War II. The narrator comments pointedly that the "future was being born" and Max was "being asked to be its midwife." future world was utterly American-centered, which is said to result in a "new captivity" with the "cycle of violence" remaining unbroken. ${ }^{51}$ By the end of the novel, the political consequences of Max's world-making are made apparent although he is killed by Shalimar for personal rather than political reasons.

Both Max and Grimus are dangerous world-makers and both are driven by their traumatic historical imaginations, in contrast to their postcolonial counterparts mired in a sorrowful unacknowledged reality. Clearly, Rushdie's novels are at pains to distinguish themselves from the dominant narrative of Jewish suffering based on a catastrophic history. A supersessionist narrative, personified by an elderly Jewish patriarch and a younger postcolonial counterpart, shapes many of Rushdie's fictions, such as The Moor's Last Sigh (1995), which contrasts the malevolent and all-controlling Abraham with his son, Moraes ("The Moor"), who is on the side of diaspora and hybridity, a "jewholic-anonymous, a cathjew nut, a stewpot, a mongrel cur ... a real Bombay mix." 52 The opposition between a Jewish patriarch and a young postcolonial figure can also be found in a range of other works from V. S. Naipaul's The Mimic Men (1967)—with Mr. Shylock, who haunts the novel, and the young Ralph Singh who mimics him-to Zadie Smith's White Teeth (2000), with the smug patriarchal Marcus Chalfen opposed by his son Josh and Smith's black-British persona, Irie. ${ }^{53}$ The engagement with the traumatic memory of the Holocaust in all of these fictions, even in the name of distancing their younger protagonists from these memories, dramatizes a fear that nascent accounts of colonized suffering will be overwhelmed by a monumental Jewish history of victimhood. The anxiety of appropriation meant that a catastrophic Jewish history was self-consciously transcended in these works and located, merely, in the past. In doing so, however, all of these imaginative works make explicit the foundational nature of a "classic" world-influencing Jewish history. Although such fear of appropriation remains unarticulated in the disciplinary formation of postcolonial studies.

When it comes to the institutional formation of memory studies in the 1990s, however, the foundational place of the Holocaust was readily acknowledged. But the centrality of the Holocaust to memory studies, where the question of traumatic memory is to the fore, proved to be problematic. As Anne Whitehead has argued, the focus on memory as trauma led to the pathologizing of memory-so that it seemed as if there was "too much memory and that it threatens to overwhelm the present." 54 It is no coincidence in this regard that both the "memory boom" and the so-called

49 Ibid., 27.

50 Ibid., 173.

51 Ibid., 170, 173.

52 Salman Rushdie, The Moor's Last Sigh (London: Jonathan Cape, 1995), 104.

53 These readings are expanded in Cheyette, Diasporas of the Mind, 32-40, 255-64.

54 Anne Whitehead, Memory (London and New York, Routledge: 2009), 7-8. 
"Holocaust boom" were phenomena of the 1990s and originated predominantly in the United States. ${ }^{55}$ This initial focus on the individual, the internal, and the traumatic, decoupled memory studies from historical studies and resulted in a series of binaries between emotion and detachment, fluidity and rigidity, subjectivity and objectivity, which pitted memory against history where history, in Raphael Samuel's phrase, becomes memory's "negative other."

Memory studies, like all disciplines, are "remarkably forgetful of their own (pre) history." 57 This forgetfulness can be noted especially when, before the "memory boom," the idea of memory and history being "dialectically related" unquestioned. As Paul Auster argued in the late 1980s, memory is "not simply ... the resurrection of one's private past but an immersion in the past of others, which is to say: history-which one both participates in and is a witness too, is both a part of and apart from." 59 Following Auster, individual and collective memory is now widely recognized as playing a key role in the construction of past histories. But, if, at the beginning of the formation of memory studies, history and memory were connected dialectically, it was only after the "memory boom" in the 1990s-which resulted in the disciplinary formation and institutionalization of memory studies-that the presentday "crisis" 60 arose concerning the question of how much history (too much or too little) should be included in the new discipline.

This uncertainty can be seen in particular in Michael Rothberg's rightly influential account of Multidirectional Memory: Remembering the Holocaust in the Age of Decolonization (Stanford University Press, 2009). Multidirectional memory, as defined by Rothberg, is a "countertradition in which remembrance of the Holocaust intersects with the legacies of colonialism and slavery and ongoing processes of decolonization."61 It is opposed, in particular, to zero-sum competitive memory, which characterizes much of the identity politics in the United States. Along with Maxim Silverman's Palimpsestic Memory: The Holocaust and Colonialism in French and Francophone Fiction and Film (2013), Rothberg focuses mainly on postwar France, which is properly described as a "laboratory" 62 where the differing histories of colonialism and Nazism overlap.

Rothberg begins with a compelling comparison of Hannah Arendt and Aimé Césaire, who both regarded Nazism as a form of colonialism brought home to Europe. Both figures, writing in the early 1950s, exemplify a time when different forms of

55 For the late twentieth-century "memory boom” see Jay Winter, Remembering War: The Great War and Historical Memory in the Twentieth Century (New Haven, CT: Yale University Press, 2006); "Holocaust Boom" was coined by Frank Rich in the New York Times in April 1994, after the mass release of the film Schindler's List and the opening of the US Holocaust Memorial Museum in Washington DC. See www.nytimes.com/1994/04/07/opinion/journal-the-holocaust-boom.html.

56 Raphael Samuel, Theatres of Memory: Past and Present in Contemporary Culture (London: Verso, 2012).

57 Whitehead, Memory, 3.

58 Samuel, Theatres of Memory, xvii.

59 Paul Auster, The Invention of Solitude (New York: Penguin, 1988), 149.

60 Richard Terdiman, Present Past: Modernity and the Memory Crisis (Ithaca, NY: Cornell University Press, 1993).

61 Rothberg, Multidirectional Memory, xiii.

62 Ibid., 107, 176. 
racism were not confined to separate disciplinary spheres as they are today. He also goes back to the figure of W.E.B. Du Bois, whose 1949 visit to Warsaw resulted in Du Bois qualifying and extending his abiding belief that the "colour line" 63 is the main problem of the twentieth century. All of this historical reconstruction is exemplary and builds on Mufti's Enlightenment in the Colony in which Mufti brought together European colonial history and the so-called "Jewish Question" by articulating the "paradigmatic narratives" of minority existence within Western culture-"assimilation, emancipation, separatism, conversion, the language of state protection and

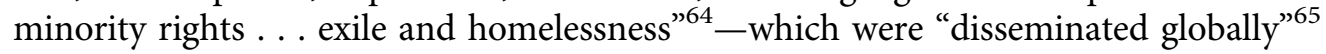
under colonial and semi-colonial conditions and were applied to the partitionary formation of nation-states, such as India and Pakistan, after decolonization. It is such partitionary formations that continue to shape many present-day histories, as Mufti stresses, whether in Kashmir or Israel/Palestine. ${ }^{66}$

Where Rothberg, however, differs markedly from Mufti is in privileging memory over history because of its greater fluidity ("memory is the past made present"). It is the "power of anachronism" Phillips that is seen by Rothberg to challenge the rigidity of a totalizing history, which results in an account of the "oscillation between re- and de-historicization" 69 in their work. In these terms it is the "power of anachronism" rather than historicization that brings together the supposed separate spheres of the histories and aftermaths of the Holocaust and European colonialism. ${ }^{70}$ By foregrounding anachronism it is assumed that such interconnected histories are lost, repressed, or marginal. That is why multidirectional memory, which is distinguished from supposedly monodimensional history, is the only means of accessing them. Rothberg's rethinking of Freud's screen memory is at the heart of the conception of multidirectionality. Rather than hiding a more disturbing truth, which usually characterizes the substitutions and displacements that constitute a screen memory, Rothberg emphasizes that screen memory "more closely resembles a remapping of memory in which links between memories are formed and then redistributed between the conscious and unconscious."

By locating the knotted histories of fascism and colonialism on the level of screen memory, history is marginalized and rendered outside our active consciousness. But the historical record when it comes to the intertwined histories of colonialism, the Holocaust and slavery, as Mark Mazower has shown most comprehensively, is not in

63 W.E.B. Du Bois, “The Negro and the Warsaw Ghetto," Jewish Life 6.7 (May 1952): 14-15.

64 Mufti, Enlightenment in the Colony, 2-3.

65 Ibid., 2.

66 My argument with Mufti is precisely the shift from a comparative perspective of partition as part of the intertwined history of colonialism and anti-Semitism to a foundational focus on Israel/Palestine as the all-explaining anticolonial cause $d u$ jour. As he says in "The Predicaments of Postcolonial Thinking": "My next book project ... is something like a sequel to Enlightenment in the Colony. It's called Edward Said in Jerusalem, and it brings the conceptual framework of the former book fully to the question of Palestine. I'm really asking, what is the significance of Palestine as historical experience for the practice of social, political, and cultural criticism at the present moment?" (151).

67 Rothberg, Multidirectional Memory, 3, 6.

68 Ibid., 136 and chapter five.

69 Ibid., 152.

70 Ibid., 136.

71 Ibid., 14. See also Silverman, Palimpsestic Memory, 20-22 and chapter one. 
the least marginal or repressed or even forgotten. ${ }^{72}$ It is now recognized increasingly that in the years immediately after World War II, anticolonial thinkers-such as Frantz Fanon, Albert Memmi, and Aimé Césaire-routinely included the aftermath of Nazism in their analysis of colonialism and those who were imprisoned in the Nazi concentration camps-such as Primo Levi and Jean Améry-looked in part to the victims of colonialism to understand their experiences. Améry, for instance, wrote an important essay on Fanon, and he regarded Fanon as an essential interlocutor. ${ }^{73}$ Disciplinary thinking of all kinds-from nationalism to identity politics to academic specialisation-has increasingly separated out these analogous histories, but that is not the same as saying that these are marginal histories. What is more, in privileging the fluidity and remapping of screen memory, history is once again in danger of becoming memory's "negative other" leading to a rejection of what Rothberg calls a "historicist perspective." ${ }^{74}$ The postmodern traversing of "ethnicity and era" ${ }^{77}$ in the name of the power of anachronism (a power that I have to admit I have always been suspicious of in the fiction of Caryl Phillips ${ }^{76}$ ) leads to the characterization of historicism as majoritarian, inflexible and falsely authoritative compared to the fluidity, plurality, and minoritarian perspective of multidirectional memory. An old and rigid historicism compared with a new and fluid memory is, once again, another form of supersessionist thinking. As the evocative "comparative thinking"77 in Rothberg's book demonstrates, historical reconstruction need not be in competition with a newly disciplined memory studies.

One reason for the distinction between an old and rigid historicism compared with a new and fluid memory is precisely the fear that the past will dominate the present; the old will dominate the new (not least given the public presence of the Holocaust in Europe and North America especially after the so-called "Holocaust boom" in the 1990s). But what is ironic about this fear of appropriation, in relation to the supposedly foundational memory of the Holocaust, is that most concentration camp testimonies are far from authoritative and need to be distinguished completely from the Holocaust as public discourse. ${ }^{78}$ Figures such as Primo Levi, Charlotte Delbo, and Jorge Semprun, most prominently, tend to foreground forgetting rather than memory and, what I call, an "ethical uncertainty" both the necessity of their memory work and their all too apparent recognition that it may well be on the side of forgetting; a betrayal of the victims.

72 Mark Mazower, Hitler's Empire: Nazi Rule in Occupied Europe (London and New York: Allen Lane, 2008).

73 Jean Améry, "The Birth of Man from the Spirit of Violence: Frantz Fanon the Revolutionary," Wasafiri 44 (Spring 2005): 13-18.

74 Rothberg, Multidirectional Memory, 25, 137.

75 Ibid., 17, my emphasis.

76 Bryan Cheyette, "Venetian Spaces: Old-New Literatures and the Ambivalent Uses of Jewish History," Reading the 'New' Literatures in a Postcolonial Era, ed. Susheila Nasta (London: Boydell \& Brewer, 2000), 53-72.

77 Rothberg, Multidirectional Memory, 18.

78 For the Holocaust as public discourse, see Tim Cole, Selling the Holocaust: From Auschwitz to Schindler; How History Is Bought, Packaged and Sold (London and New York: Routledge, 1999).

79 "The Ethical Uncertainty of Primo Levi" in Cheyette and Marcus, Modernity, Culture and "the Jew," chapter seventeen. 
The works of Semprun and Delbo, in particular, are as much about forgetting as they are about memorializing. Delbo's distinction between "deep" and "intellectual" memory, for instance, is predicated on the latter kind of memory as a self-conscious form of forgetting: "when I talk to you about Auschwitz, it is not from deep memory my words issue.... For it isn't words which are swollen with emotional charge." 80 Turning memory into narrative is, precisely, a form of forgetting as this kind of intellectual memory is disembodied and does not "preserve ... sensations, physical imprints." 81 Semprun's The Long Voyage (1964) is similarly predicated on sixteen years of forgetting before he self-consciously writes a historical metafiction where the mimetics of the process of remembering (to adapt Linda Hutcheon's formulation) become his fictionalized memoir. ${ }^{82}$ Semprun, like Delbo, incorporates forgetting into his account of his transport to Buchenwald because "everything you might write risks having too much gravity" and leads him back to "death" or the concentration camp. ${ }^{83}$ The physical imprint of "deep memory" cannot be transformed into narrative. By the time of his posthumous The Drowned and the Saved (1986), Levi was also deeply suspicious of "intellectual memory," even though he once believed that he had not forgotten a single thing of his time in the camps. ${ }^{84}$ Looking back at his time in Auschwitz, after four decades, he argues that:

I really would have given bread and soup-that is blood-to save from nothingness those memories which today with the sure support of printed paper I can refresh gratis whenever I wish, and which therefore seem of little value. Then and there they had great value. ${ }^{85}$

Levi, at his most pessimistic, felt that he no longer had access to his "deep" memories. This is what I mean by the ethics of uncertainty that incorporates the act of forgetting into camp testimonies. Acknowledging that memory is a "suspect source," ${ }^{\prime 6}$ as Levi puts it, means that when his memory self-consciously fails him, he is at pains to bear witness to those moments of failure whenever they occur. The key point that I want to make is a paradoxical one. Although the testimonies of these survivors tend to reinforce a sense of memory as uncertain, fluid, and lacking authority, they also undermine the foundational status of the Holocaust in relation to memory studies. History, as represented in their testimonies, is no longer memory's Other and remains alive and always open to interpretation in their work. What does this then say about the foundational status of the Holocaust and its construction as an authority (at least for memory studies) where none exists?

80 Charlotte Delbo, Days and Memories, trans. Rosette C. Lamont (London: Malboro, 1985), 3 and 1-4; Charlotte Delbo, Auschwitz and After, trans. Rosette C. Lamont (New Haven, CT: Yale University Press, 1995), throughout.

81 Delbo, Days and Memories, 3.

82 Linda Hutcheon, A Poetics of Postmodernism: History, Theory, Fiction (London and New York: Routledge, 1988), throughout.

83 Jorge Semprun, Literature of Life, trans. Linda Coverdale (New York: Viking 1997), 161 and chapter six; Jorge Semprun, The Long Voyage, trans. Richard Seaver (New York, 1964), throughout.

84 Primo Levi, Moments of Reprieve, trans. Ruth Feldman (London and New York: Penguin, 1981 ), 11.

85 Primo Levi, The Drowned and the Saved, trans. Raymond Rosenthal (London and New York: Abacus, 1986), 112.

86 Ibid., 29 and $15-30$. 
To help overcome this impasse, I want to focus briefly on "diaspora" and "ghetto" as "traveling concepts," ${ }^{87}$ after Mieke Bal, who speaks of interdisciplinary concepts that travel between disciplines and change by doing so. For Bal, "a negotiation, a transformation, a reassessment" ${ }^{88}$ of the concept is needed at each stage of travel. Diaspora and ghetto are traveling concepts not only in disciplinary terms (going between Jewish, postcolonial, and racial and ethnic studies, for instance) but also change meaning and formation throughout a long history. Equally important are the different historical turns taken, as well as the interconnected paths traveled historically by each concept. The main problem with the binary thinking that I have outlined is it tends to close off historical narratives and points of travel and dialogue between concepts. Robin Cohen's Global Diasporas: An Introduction (1997), for instance, constructs the Jewish diaspora as a "classic diaspora" only to be transcended by newer, more contemporary diasporas: "Classical notions of diaspora: Transcending the Jewish tradition" is the title of his first chapter. ${ }^{89}$ One main problem with this established approach is that it reinforces the reductive narrative that diasporic Jewish history has ended with the European Holocaust, which is, paradoxically, also the narrative of Jewish nationalism. What is exemplary about Quayson and Daswani's introduction to their Companion to Diaspora and Transnationalism (2013) is that they, too, construct the Jewish diaspora (among other diasporas such as the Armenian diaspora) as "classic" but, at the same time, locate different formations of the Jewish diaspora historically and transnationally and therefore avoid the trap of either supersessionist thinking or of constructing the Jewish diaspora as foundational (not least because, as they righty argue, the word diaspora is taken from the Hellenic rather than the Hebraic tradition). ${ }^{90}$ As Bal contends, negotiation, transformation, reassessment leads to a more nuanced approach rather than transcendence, supersession, and replacement.

As well as iconizing the past as "classic," we also have to be aware of the dangers of fetishizing the present as "new." It was only in 1972 that the Oxford English Dictionary included a definition of "contemporary" that made it synonymous with "new." Before that date "contemporary" meant primarily "belonging to the same time." What happened in the 1970s to change the definition of contemporary to make it new? Clearly, it is no coincidence that the meaning of contemporary changed to new at the same time as postmodernism was in usage-a term that can be said to have universalized the idea of the new in the late capitalist West. But, by confusing the new and the contemporary, our supposedly postmodern times may be thought of as lacking antecedents, which makes them prey to supersessionist and foundational thinking.

That is why the various discourses around diaspora and the ghetto can be thought of productively as traveling concepts that are neither foundational nor transcendent (under the sign of the new). To be sure these are contested terms with diaspora, in one incarnation, leading to a world of autochthonous nation-states (not least in Israel/ Palestine) and ghetto used as a form of denigration. Although these concepts remain

87 Mieke Bal, Travelling Concepts in the Humanities (Toronto, Canada: Toronto University Press, 2002).

88 Ibid., 39 and chapter one.

89 Robin Cohen, Global Diasporas: An Introduction (London and New York: Routledge, 1997), chapter one.

90 Quayson and Daswani, "Introduction: Diaspora and Transnationalism," 8-9.

91 Luckhurst and Marks, Literature and the Contemporary, 1. 
contested, it would be a mistake merely to separate out the history of the ghetto or diaspora into old and new, postcolonial and Jewish. Such separate spheres mean that the different histories and cultures of ghetto and diaspora can never be in dialogue with each other. The history of the ghetto, for instance, moves from the mainly but not exclusively Jewish ghettos in medieval and early modern Europe beginning in Venice, at least terminologically, in 1516. By the nineteenth century, ghetto was used with reference to virtually all major urban conurbations in Europe and North America in relation to the supposed ghettoization of the massive influx of Jewish refugees from Eastern Europe. As Mitchell Duneier has documented, by the 1940s there was a historical turn from the Nazi ghettos in modern Europe to the mainly but not exclusively African American ghettos in many of America's large northern cities. ${ }^{92}$ This turn happened because the Nazi reghettoization of Europe (supposedly based on the medieval model) was extensively reported in the United States and witnessed by African American soldiers who helped to liberate the camps. From the 1940s onward, the term was adopted by the black urban poor and incorporated into music, film, and popular culture of all kinds. By the twenty-first century, the concept of the ghetto has been both globalized and commodified and has also been a source of self-identification and resistance by the urban poor throughout the world. Ghetto, in other words, is a traveling concept par excellence. Given the spatial fixity of ghettos (over half a millennia), it is possible to track the shift from one kind of ghetto to another across time and place and especially the cultural exchange between different kinds of ghettos.

Once again, though, we have the issue of supersessionism and foundationalism with the Jews universally associated with the first European ghettos (beginning in Renaissance Italy and located thereafter throughout Western Europe). More perniciously, American Jews have been constructed as a model minority (among many whitened minorities) who have moved out of the ghetto in stark contrast to African Americans who are particularly stigmatized and blamed for their supposed inability to leave the ghetto (as if they are not victims of now widely acknowledged discriminatory urban planning in many of America's major cities). ${ }^{93}$ The term ghetto traverses radically differing histories, once again constructing Jews as foundational and as ideal types, in stark contrast to African Americans who are deemed to come after and fail by these standards. But that is no reason to supersede an earlier history in the name of the new and contemporary. In fact, I would argue, that one cannot understand anti-black racism in North America (where African Americans are deemed not to have followed the path of modernity) without these other histories in dialogue.

Why do I stress the need to decenter Jewish history so that it can be perceived as unexceptional? This is, above all, a response to what I regard as deep-seated binary thinking both inside and outside the academy that still saturates Western culture. As one of Aamir Mufti's left-liberal "folks in Jewish studies," the pressure to take sides in relation to Israel/Palestine is enormous even when the ingrained politics of the conflict has taken a malign form of radical Manicheanism ("fascists" versus "new

92 Mitchell Duneier, Ghetto: The Invention of a Place, the History of an Idea (New York: Farrar, Straus and Giroux, 2016), chapter one.

93 Ibid., chapter four. 
Jews" or "Islamo-fascists" versus Israeli Jews) that imprisons thought. That is why Adorno resisted a hard and fast distinction between theory and praxis and maintained that the primacy of praxis was regressive. Those who disagree with Adorno's argument assume that any action that is not clearly and unequivocally part of a new "antifascist" politics is at best quietist and at worst unethical. By insisting on Israel/ Palestine as being at the front and center of anticolonialism $d u$ jour, Jewish history is reinforced mistakenly as always already foundational and in dire need of superseding. To be sure, the repressive practices of the Israeli State do speak to a sense of Israel as being out of time: practicing a form of neocolonial rule that supposedly ended with decolonization more than half a century ago. But it is crucial to resist the presupposition that Jews are out of time ("old" and not "new"), which mirrors Jewish fundamentalists who also believe that Jews belong to a different (biblical) age.

The temptation to become a "good Jew" in such circumstances is overwhelming. As much as I would like to be considered a "good Jew," on the side of the angels, I am, however, too aware of my less than human counterparts or "bad Jews," who accompany "good Jewish" actionists. To be sure, this diasporic anxiety may well be considered secondary (to say the least) to the suffering peoples on the ground in Palestine since 1948. Perhaps it is the fate of diaspora peoples to be faced with impossible choices. But that is the reason why I call, once again, for Jews and Palestinians to be treated as fully rounded human beings - rather than as part of an exceptional or foundational history-and for a perception of Israel/Palestine as not just a pariah-making one-sided crime but as a tragic all too human conflict. ${ }^{94}$ Only in this cultural context will the awkward, compromised, and impure humanity on all sides of a centuries-old confrontation be acknowledged. That is why supersessionist thinking is so regressive. It makes it impossible to find connections in the past and in our most urgent present between different forms of dehumanization-orientalism, anti-Semitism, and Islamophobia-and between shared forms of suffering (not least as refugees) alongside an often violent agency. The nascent project to place Jewish and postcolonial studies in critical dialogue is, I would like to believe, a form of praxis on the side of peace and justice. And, needless to say, this theory/praxis does urgently need to be accompanied by what Adorno called "thinking actionism.. ${ }^{95}$

\section{Notes}

This article began life as a plenary address at a May 2015 conference on "Memory Frictions: Conflict, Negotiation, Politics" (University of Zaragoza). I would like to thank the organizers, María Jesús Martínez-Alfaro and Silvia Pellicer-Ortín, for their invitation and encouragement. The paper has been delivered subsequently in research seminars at the University of Sussex, the Institute of Historical Research, London, and at the Centre for Diaspora and Transnational Studies, University of Toronto. I am particularly grateful for feedback, in its different incarnations, from Peter Boxall, Martin Eve, David Feldman, Willi Goetschel, Ivan Kalmar, Denise Decaires Narain, and Ato Quayson.

94 As Edward Said argues in "My Right of Return": "when you think about Jew and Palestinian not separately, but as part of a symphony, there is ... a series of tragedies, of losses, of sacrifices ..." in Power, Politics and Culture: Interviews with Edward W. Said, ed. Gauri Viswanathan (New York: Pantheon, 2001), 445 and 443-58.

95 Adorno, Critical Models, 290. 